\title{
MENDONGKRAK AUTENTISITAS PENILAIAN BAHASA INGGRIS MELALUI PENERAPAN SISTEM PENILAIAN ELASI
}

\author{
Teddy Fiktorius \\ SMA Bina Mulia Pontianak, Kalimantan Barat \\ Email: fiktoriusteddy@yahoo.com
}

\begin{abstract}
Abstrak
Ujian Nasional (UN) mata pelajaran bahasa Inggris pada jenjang SMA memunculkan polemik terkait distorsi autentisitas penilaian. UN bahasa Inggris yang hanya mengukur keterampilan mendengarkan dan membaca melalui seperangkat instrumen tes berbentuk pilihan ganda tidak mendukung eksistensi autentisitas penilaian. Melalui kajian mendalam terhadap literatur dan dokumen yang tersedia serta pengamatan lapangan, sebuah produk inovatif berupa sistem penilaian bertajuk English Language Assessment System in Indonesia (ELASI) digagas oleh penulis sebagai langkah korektif yang menawarkan solusi untuk mendukung pelaksanaan penilaian bahasa Inggris yang mengedepankan autentisitas. Gagasan ilmiah ELASI berorientasi pada pemenuhan autentisitas penilaian dari aspek relevansi karakteristik tes dengan kondisi nyata kehidupan sehari-hari dan implementasi kemampuan berpikir aras tinggi.
\end{abstract}

Kata kunci: autentisitas penilaian, tes, ELASI, kemampuan berpikir aras tinggi

\section{Pendahuluan}

Dalam konteks penilaian mata pelajaran Bahasa Inggris melalui Ujian Nasional jenjang Sekolah Menengah Atas (SMA) di Indonesia, perdebatan akan pentingnya kualitas perangkat tes menjadi bahan diskusi argumentatif perihal autentisitas penilaian. Giraldo (2018) menjelaskan bahwa perangkat tes seyogyanya tidak mengesampingkan substansi komunikatif di mana autentisitas penilaian menjadi hal yang mutlak dalam mengukur kecakapan bahasa Inggris secara komprehensif. Perdebatan tersebut kemudian memunculkan asumsi publik terkait tidak optimalnya autentisitas penilaian pada Ujian Nasional mata pelajaran bahasa Inggris di Indonesia. Autentisitas penilaian dimaknai sebagai luasnya hubungan antara karakteristik perangkat tes dengan kondisi yang sesungguhnya dalam kehidupan sehari-hari (Valencia dkk., 2014).

Seperti pada tahun-tahun pelaksanaan Ujian Nasional sebelumnya, kisi-kisi Ujian Nasional mata pelajaran Bahasa Inggris yang terlampir di dalam Surat Keputusan Badan Standar Nasional Pendidikan (BSNP) No. 0282/SKEP/BSNPVIII/2017 tentang kisi-kisi Ujian Nasional untuk Satuan Pendidikan Dasar dan Menengah Tahun Pelajaran 2017/2018 menyiratkan bahwa ujian tersebut hanya mencakup materi tes terkait keterampilan mendengarkan dan keterampilan membaca di dalam bentuk tes pilihan ganda. Proporsi tersebut merujuk pada isu autentisitas yang berkaitan erat dengan kurikulum yang telah menjadi panduan pelaksanaan pembelajaran bahasa Inggris jenjang SMA di Indonesia yang dirumuskan oleh Kementerian Pendidikan dan Kebudayaan Republik Indonesia. Tujuan pembelajaran yang dijabarkan dalam kurikulum mata pelajaran bahasa Inggris secara jelas tidak hanya untuk meningkatkan keterampilan mendengarkan dan keterampilan membaca, tetapi juga keterampilan berbicara dan keterampilan menulis.

Sebagai konsekuensi logis dari paparan di atas, ujian bahasa Inggris yang mengabaikan penilaian terhadap keterampilan berbicara dan keterampilan menulis dapat dikategorikan sebagai ujian yang tidak memiliki autentisitas. Abedi (2010) mengungkapkan bahwa ujian tersebut tidak mampu memberi kesempatan kepada peserta didik untuk mempresentasikan gambaran yang komprehensif tentang apa yang mereka ketahui dan mampu mereka lakukan sebagai hasil dari sebuah proses pembelajaran. Oleh karenanya, guru dan pemangku kepentingan terkait mulai 
mempertanyakan kualitas sistem penilaian pada Ujian Nasional mata pelajaran bahasa Inggris. Selanjutnya, distorsi autentisitas penilaian tersebut berimbas pada mutu instruksi pembelajaran bahasa Inggris di konteks kelas. Guru ditempatkan pada situasi dilematis. Di satu sisi, guru diharapkan untuk menyajikan pembelajaran sesuai tuntutan kurikulum, yakni pembelajaran yang melibatkan upaya peningkatan seluruh keterampilan bahasa Inggris. Di sisi lain, guru dihadapkan pada situasi di mana pembelajaran perlu mendukung kesuksesan pencapaian nilai maksimal pada Ujian Nasional bahasa Inggris.

Beranjak dari argumentasi di atas, penulis mengeksplorasi lebih lanjut dengan tujuan berupa upaya untuk memaparkan gagasan ilmiah pemecahan masalah melalui penerapan sistem penilaian ELASI, yakni akronim dari English Language Assessment System in Indonesia, sebagai usaha untuk menjawab urgensi autentisitas pembelajaran dan penilaian dengan memberikan umpan balik berupa gagasan ilmiah tentang autentisitas penilaian.

\section{Autentisitas Penilaian}

Substansi pembahasan perihal penilaian autentik tidak terlepas dari pembahasan mengenai penilaian tradisional. Penilaian tradisional mengandalkan penilaian yang berbasis pada format tes pilihan ganda, jawaban singkat, uraian, dan bentuk tes lainnya yang hanya menguji keterampilan yang terisolasi dalam ranah penghafalan informasi atau pengetahuan. Pada Ujian Nasional mata pelajaran bahasa Inggris, serangkaian butir soal yang digunakan adalah berbentuk pilihan ganda. Atas dasar pemikiran ini, maka ujian tersebut dikategorikan ke dalam penilaian tradisional. Valencia dkk. (2014) mengemukakan bahwa penilaian tradisional tidak memiliki kemampuan untuk mengukur kecakapan peserta didik secara efektif dan menyeluruh. Lebih spesifik, Valencia dkk. (2014) menjabarkan tiga argumen dasar terkait keterbatasan format tes pilihan ganda sebagai berikut.

1. Butir soal pilihan ganda tidak efektif untuk mengukur pemecahan masalah dan kemampuan untuk mengatur dan mengekspresikan gagasan.

2. Butir soal pilihan ganda berfokus pada pengujian informasi faktual dan gagal untuk menguji tingkat pemikiran kognitif yang lebih tinggi.

3. Butir soal pilihan ganda tidak memberikan ukuran kemampuan komunikatif berupa keterampilan menulis dan keterampilan berbicara.

Sebagai respons atas kelemahan penilaian tradisional, para guru dan pemangku kepentingan di ranah pendidikan mulai beralih kepada urgensi autentisitas penilaian. Fenomena tersebut semakin berkembang ketika guru memiliki perhatian lebih kepada penilaian yang memiliki pendekatan yang holistik, yakni penilaian yang dapat mengukur kemampuan peserta didik secara lebih komprehensif. Secara spesifik, guru mata pelajaran bahasa Inggris memberikan perhatian lebih terhadap pembelajaran yang komprehensif berdasarkan muatan kurikulum mata pelajaran bahasa Inggris dan penilaian yang dapat mengukur kecakapan peserta didik secara menyeluruh yang mencakup empat keterampilan Bahasa, yakni keterampilan mendengarkan, keterampilan berbicara, keterampilan membaca, dan keterampilan menulis. Pernyataan di atas sejalan dengan argumen Abedi (2010) yang menekankan penilaian autentik yang bersumber dari konstruksi bahasa, yakni keempat keterampilan tersebut. Argumentasi di atas mengisyaratkan bahwa keterampilan berbicara dan keterampilan menulis yang dikategorikan ke dalam domain keterampilan produktif membutuhkan penilaian kinerja.

Atas dasar pemikiran itu, dapat digarisbawahi bahwa penilaian autentik menekankan hubungan penilaian dengan kehidupan sehari-hari di dunia nyata. Penilaian autentik tidak berakhir di atas secarik kertas saja, namun makna dan faedah dari penilaian tersebut sangat erat kaitannya dengan situasi nyata di kehidupan sehari-hari para peserta didik. Chandio dan Jafferi (2015) menjelaskan bahwa penilaian autentik adalah penilaian yang berbasis kinerja yang melibatkan aktivitas- 
aktivitas yang dapat dijumpai di dalam kehidupan sehari-hari. Dengan kata lain, penilaian autentik mengharuskan para peserta didik untuk melakukan unjuk kerja atau demonstrasi kinerja. Lebih terperinci, penilaian autentik melibatkan peserta didik untuk tidak hanya menunjukkan penguasaan ilmu pengetahuan saja, namun juga mengembangkan seperangkat keterampilan dan mengaplikasikannya ke dalam situasi kehidupan sehari-hari.

Secara singkat, dapat disimpulkan bahwa autentisitas penilaian bersinggungan dengan ranah kognitif yang lebih tinggi (higher-order thinking skills) yang mengharuskan peserta didik mengaplikasikan apa yang mereka tahu, bukan semata-mata menghafal. Di samping itu, tolok ukur kesuksesan penilaian autentik adalah kesesuaian antara substansi pembelajaran dan substansi penilaian yang merefleksikan situasi di kehidupan nyata.

\section{Pembelajaran Autentik}

Secara konseptual, penilaian autentik mencerminkan pembelajaran autentik. Pernyataan ini menyiratkan bahwa pelaksanaan penilaian autentik tidak terlepas dari pengaruh pembelajaran autentik. Pengaruh ini diartikan sebagai hubungan sebab-akibat antara penilaian dan pembelajaran. Di satu sisi, penilaian yang autentik merupakan penilaian yang memiliki kemampuan untuk mengukur ketercapaian pembelajaran yang autentik. Di sisi lain, keberhasilan pada pembelajaran autentik memungkinkan peserta didik untuk mencapai hasil yang optimal dalam penilaian autentik. Maka dari itu, elaborasi terkait pembelajaran autentik perlu dibahas di dalam kerangka teoritis penilaian autentik. Palm (2008) menegaskan bahwa diskusi mengenai pembelajaran autentik terintegrasi dengan penilaian autentik. Argumen ini bermakna bahwa pembahasan kedua substansi tersebut tidak dapat berdiri sendiri.

Selanjutnya, pembelajaran autentik memiliki perspektif yang didasarkan pada sudut pandang bahwa tujuan utama dari penilaian adalah untuk pengembangan pembelajaran. Palm (2008) menjelaskan bahwa penilaian dapat diklaim autentik hanya jika penilaian tersebut efektif untuk meningkatkan pembelajaran. Lebih lanjut, Palm (2008) menekankan bahwa pembelajaran dapat dikategorikan sebagai pembelajaran yang autentik jika pembelajaran tersebut membantu para peserta didik untuk mencapai dua tujuan pembelajaran utama, yakni peserta didik mampu menggunakan pendekatan inkuiri untuk mengonstruksi dan menghasilkan pengetahuan (bukan menghafal pengetahuan) serta menghasilkan produk maupun kinerja yang memiliki makna di kehidupan sehari-hari. Sejalan dengan teori Palm, Valencia dkk. (2014) menjelaskan pentingnya aplikasi keterampilan berpikir aras tinggi di dalam pembelajaran autentik. Keterampilan berpikir aras tinggi yang dimaksud mencakup keterampilan dalam berpikir kritis dan kreatif, memecahkan masalah, menyampaikan argumen, dan mengambil keputusan. Teori ini didukung oleh hasil penelitian yang dilaksanakan oleh Halili (2015) dan Karakoc (2016) yang berkesimpulan bahwa urgensi penerapan HOTS dalam setiap tahap pembelajaran semakin mendesak dalam abad 21.

Ranah kognitif tingkat tinggi pada pembelajaran autentik berkaitan erat dengan proses kognitif yang dimiliki oleh orang dewasa pada usia produktif yang berkecimpung dalam dunia kerja sehari-hari. Palm (2008) mengemukakan sebuah perspektif pembelajaran autentik yang menargetkan tidak hanya pada pencapaian di akhir pembelajaran, tetapi juga keberhasilan setelah masa sekolah, yakni masa ketika para peserta didik terjun ke dunia kerja. Sehubungan dengan pernyataan tersebut, dapat digarisbawahi bahwa para pemangku kepentingan dan pengambil keputusan di dunia pendidikan perlu meramu kurikulum yang mampu berjalan seirama dengan kondisi dunia kerja. Dengan kata lain, pembelajaran autentik memiliki dua dimensi, yaitu dimensi pembelajaran dalam kelas dan dimensi pencapaian di dunia kerja. 


\section{Metodologi}

Gagasan ilmiah produk inovatif berupa sistem penilaian bahasa Inggris bertajuk English Language Assessment System in Indonesia (ELASI) dilakukan melalui kajian mendalam terhadap literatur dan dokumen yang tersedia serta pengamatan lapangan.

\section{Pembahasan}

Pada bagian pembahasan, penulis pertama-tama memaparkan analisis kesenjangan antara kondisi ideal dan kondisi nyata pada penerapan sistem penilaian mata pelajaran bahasa Inggris jenjang SMA di Indonesia dalam relevansinya dengan autentisitas penilaian. Kemudian, gagasan pemecahan masalah disajikan dengan didukung oleh penyajian tabel guna memberikan pemahaman yang lebih komprehensif.

\section{Kondisi Ideal}

Perhelatan tahunan Ujian Nasional bahasa Inggris jenjang SMA senantiasa memantik reaksi pro dan kontra di kalangan masyarakat, terutama para guru bahasa Inggris. Pembahasan pada artikel ini tidak beranjak dari sebuah urgensi untuk menjabarkan jawaban eksplanatoris dan jawaban deskriptif perihal kontroversi pelaksanaan Ujian Nasional bahasa Inggris, melainkan topik yang substantif, yakni autentisitas penilaian.

\section{Relevansi dengan Kehidupan Nyata}

Berpegang erat pada teori-teori autentisitas penilaian yang diajukan oleh Abedi (2010) serta Valencia dkk. (2014), penulis menarik garis besar bahwa Ujian Nasional bahasa Inggris yang ideal adalah ujian yang menggunakan perangkat tes yang mengutamakan substansi komunikatif, yakni kecakapan yang aplikasinya sangat erat kaitannya dengan kondisi nyata di kehidupan sehari-hari. Autentisitas penilaian menitikberatkan hubungan antara karakteristik instrumen tes yang dipakai di dalam Ujian Nasional bahasa Inggris dengan keadaan nyata yang ditemui di dalam kehidupan sehari-hari. Ujian Nasional bahasa Inggris saat ini yang hanya mengukur kemampuan bahasa Inggris peserta didik pada keterampilan mendengarkan dan keterampilan membaca sewajarnya juga mencakup pengujian pada keterampilan berbicara dan keterampilan menulis. Kedua keterampilan ini, pada kenyataannya, merupakan keterampilan komunikatif yang senantiasa diperlukan dan dipergunakan di dalam interaksi sosial sehari-hari di seluruh aspek kehidupan. Lebih lanjut, elaborasi di atas selaras dengan pendekatan holistik yang idealnya diterapkan pada Ujian Nasional bahasa Inggris. Pendekatan holistik tersebut mengarah pada penilaian yang komprehensif, yakni penilaian yang dapat mengukur kecakapan peserta didik secara menyeluruh yang mencakup empat keterampilan bahasa. Pemikiran ini bertolak dari kajian teori oleh Abedi (2010) yang menekankan pentingnya eksistensi konstruksi bahasa, yakni keempat keterampilan tersebut, pada setiap perangkat tes bahasa.

\section{Implementasi Kemampuan Berpikir Aras Tinggi}

Tes bahasa yang ideal juga menjunjung tinggi penerapan kemampuan berpikir aras tinggi. Pemikiran ini mengindikasikan bahwa autentisitas Ujian Nasional juga erat kaitannya dengan keterlibatan peserta didik di dalam penerapan apa yang mereka tahu, bukan semata-mata penghafalan informasi. Lebih jauh, hal tersebut berimplikasi pada urgensi penerapan penilaian kinerja yang semakin mendesak pada Ujian Nasional bahasa Inggris. Penilaian kinerja didefinisikan sebagai kegiatan pengukuran kecakapan peserta didik yang melibatkan proses kognitif menganalisa informasi yang telah diperoleh sebelumnya, menghasilkan sesuatu yang baru dari hasil analisa, serta melakukan evaluasi atas hasil karya tersebut (Abedi, 2010; Valencia dkk., 2014). Tentu saja proses kognitif tingkat tinggi tersebut tidak dapat diaplikasikan ke dalam 
soal pilihan ganda yang selama ini diandalkan pada penerapan Ujian Nasional bahasa Inggris.

Pada akhirnya, penulis menarik kesimpulan bahwa Ujian Nasional bahasa Inggris seyogyanya menekankan pada pengukuran kecakapan peserta didik pada empat keterampilan bahasa, yakni mendengarkan, berbicara, membaca, dan menulis, dengan berbasis penilaian kinerja yang berkaitan erat dengan kondisi nyata di kehidupan sehari-hari. Ketika kedua elemen tersebut hadir dalam Ujian Nasional bahasa Inggris, maka dapat dipastikan ujian tersebut memiliki autentisitas penilaian yang optimal.

\section{Kondisi Nyata}

Berdasarkan observasi lapangan, penulis mengemukakan beberapa kondisi nyata yang menggambarkan distorsi autentisitas penilaian serta nilai karakter jiwa nasionalisme pada Ujian Nasional bahasa Inggris. Elaborasi kondisi nyata tersebut mengacu pada butir-butir pemikiran yang telah dipaparkan pada bagian pembahasan sebelumnya, yakni Kondisi Ideal.

\section{Relevansi dengan Kehidupan Nyata}

Kisi-kisi Ujian Nasional mata pelajaran Bahasa Inggris yang terlampir di dalam Surat Keputusan Badan Standar Nasional Pendidikan (BSNP) termasuk yang terkini, yakni lampiran No. 0282/ SKEP/BSNPVIII/2017 tentang kisi-kisi Ujian Nasional untuk Satuan Pendidikan Dasar dan Menengah Tahun Pelajaran 2017/2018 menyiratkan bahwa terdapat dua keterampilan bahasa, yaitu keterampilan mendengarkan dan keterampilan membaca yang diujikan dalam bentuk tes pilihan ganda. Bertolak dari butir pemikiran Palm (2008), instrumen tes tersebut dikategorikan tidak memiliki kemampuan untuk menampilkan gambaran menyeluruh atas kemampuan peserta didik sebagai hasil proses pembelajaran.

Selanjutnya, penulis menarik kesimpulan bahwa fokus penilaian komunikatif, yakni keterampilan berbicara dan keterampilan menulis, tidak dapat dilaksanakan mengingat jumlah peserta ujian yang sangat besar. Disampaikan oleh Kepala Pusat Penilaian Pendidikan Badan Penelitian dan Pengembangan Kementerian Pendidikan dan Kebudayaan Republik Indonesia di dalam sebuah wawancara press pada tanggal 9 April 2018 bahwa terdapat sejumlah 1.812 .565 peserta ujian pada pelaksanaan Ujian Nasional pada tahun 2018. Jumlah tersebut mengakibatkan pada desakan untuk kecepatan dalam pengolahan nilai, yang selanjutnya mengharuskan pada penerapan proses penskoran melalui sistem komputerisasi. Fenomena ini merefleksikan bahwa bentuk soal tes yang mendukung penskoran melalui sistem komputerisasi adalah pilihan ganda, yang akhirnya bermakna bahwa keterampilan berbicara dan keterampilan menulis tidak dapat diujikan dalam pelaksanaan Ujian Nasional mata pelajaran Bahasa Inggris. Bertolak dari argumen tersebut, ujian mata pelajaran Bahasa Inggris yang mengabaikan penilaian terhadap keterampilan berbicara dan keterampilan menulis diklaim sebagai ujian yang tidak memiliki autentisitas.

\section{Implementasi Kemampuan Berpikir Aras Tinggi}

Ujian Nasional bahasa Inggris yang berbasis pada bentuk soal tes pilihan ganda dikategorikan sebagai penilaian tradisional. Penilaian tradisional berorientasi pada pengujian keterampilan yang terisolasi dalam proses kognitif tingkat rendah, yakni penghafalan informasi. Implikasi dari pernyataan tersebut mencerminkan kelemahan atau kekurangan dari bentuk tes pilihan ganda. Lebih terperinci, butir soal pilihan ganda yang dipakai di dalam Ujian Nasional bahasa Inggris tidak dapat mengukur keterampilan peserta didik dalam ranah pemecahan masalah yang secara absolut memerlukan keterampilan berpikir aras tinggi. 


\section{Gagasan Ilmiah Pemecahan Masalah \\ Rancangan Konseptual Pelaksanaan}

Dengan memerhatikan butir pemikiran terkait kesenjangan antara kondisi ideal dan kondisi nyata, penulis mengemukakan sebuah gagasan inovatif terkait sistem penilaian yang ideal pada pelaksanaan Ujian Nasional bahasa Inggris di Indonesia. Sistem penilaian inovatif tersebut mengandalkan instrumen tes yang secara komprehensif dapat mencerminkan kemampuan peserta pada masing-masing keterampilan mendengarkan, berbicara, membaca, dan menulis. Penulis mengarahkan gagasan inovatif ini sebagai solusi atas masalah distorsi autentisitas penilaian pada Ujian Nasional bahasa Inggris. Pemerintah sebagai pengambil kebijakan perlu mengembangkan sebuah sistem penilaian Bahasa Inggris yang memiliki standar lebih tinggi. Penulis menggagaskan sebuah sistem penilaian yang dapat diterapkan oleh pemerintah, yakni ELASI yang merupakan akronim dari English Language Assessment System in Indonesia. Istilah teknis tersebut dimaknai sebagai sebuah sistem penilaian bahasa Inggris di Indonesia.

Terlepas dari apapun nama dan akronim dari sistem penilaian ini, yang menjadi perhatian utama adalah bahwa Ujian Nasional bahasa Inggris perlu dikembangkan untuk menjawab urgensi autentisitas penilaian. Di dalam sistem penilaian ELASI, pengolahan hasil ujian merujuk pada nilai perolehan untuk masing-masing komponen ujian berupa skor individu untuk masing-masing keterampilan sehingga skor perolehan tersebut dapat benar-benar mencerminkan kemampuan masing-masing keterampilan bahasa yang diuji. Pada akhirnya skor-skor individu masing-masing keterampilan tersebut dijumlahkan untuk kemudian diperoleh nilai rata-rata yang menggambarkan kemampuan peserta didik dalam bahasa Inggris sebagai sebuah mata uji.

\section{Rancangan Strategis Pelaksanaan}

Penulis mengelaborasikan komponen-komponen penilaian yang diterapkan di dalam sistem penilaian ELASI sebagai berikut.

- Uji Keterampilan Mendengarkan

Pada uji keterampilan mendengarkan versi ELASI, peserta didik diperdengarkan sejumlah rekaman audio berbasis teks. Teks tersebut meliputi teks monolog maupun dialog yang melibatkan dua orang atau lebih. Untuk pengujian keterampilan mendengarkan, bentuk butir soal tes yang dapat dipergunakan adalah pilihan ganda, isian singkat, dan menjodohkan. Pilihan ganda menjadi primadona mengingat lembar jawaban ujian dapat dilakukan penskoran secara cepat, terlebih dengan menggunakan penskoran berbasis komputer.

- Uji Keterampilan Berbicara

Uji keterampilan berbicara versi ELASI menerapkan pengujian melalui presentasi singkat atau monolog perihal topik tertentu. Bentuk pengujian tersebut berbasis kinerja, di mana peserta didik dinilai berdasarkan kemampuan Bahasa Inggris yang bersifat komunikatif. Pada proses pengolahan nilai, rubrik penskoran pada penilaian kinerja dirancang dan digunakan untuk menghindari subjektifitas dalam pemberian skor. Pernyataan tersebut sejalan dengan teori Valencia dkk. (2014) yang menekankan bahwa penggunaan rubrik penskoran menjamin konsistensi yang mencerminkan objektifitas dalam penskoran.

- Uji Keterampilan Membaca

Pada uji keterampilan membaca versi ELASI, peserta ujian disajikan beberapa teks bacaan yang diambil dari buku, majalah, jurnal, dan koran berdasarkan kesesuaian materi ujian yang tersaji di kisi-kisi Ujian Nasional Bahasa Inggris. Untuk pengujian keterampilan membaca, bentuk butir soal tes yang dapat dipergunakan adalah pilihan ganda, isian singkat, menjodohkan, dan sebagainya. Pilihan ganda menjadi opsi yang tepat mengingat bentuk 
butir soal demikian memungkinkan pengolahan hasil ujian secara cepat, terlebih dengan menggunakan penskoran berbasis komputer.

- Uji Keterampilan Menulis

Pada uji keterampilan menulis versi ELASI, peserta didik diharapkan untuk menampilkan keterampilan mengembangkan argumen dalam bentuk tulisan. Sama halnya dengan uji keterampilan berbicara versi ELASI, uji keterampilan menulis juga berbasis kinerja. Peserta didik menghasilkan produk berupa karya esai opini atau argumentasi. Sebagai konsekuensi logis atas butir pemikiran di atas, isu autentisitas dapat terakomodir dengan optimal. Pernyataan demikian sejalan dengan pernyataan Hughes (2014) yang menekankan bahwa esai argumentasi menyokong pengembangan HOTS. Pada proses pengolahan nilai, rubrik penskoran dirancang dan digunakan untuk menghindari subjektifitas dalam pemberian skor.

Perbandingan komponen-komponen penilaian pada Ujian Nasional bahasa Inggris versi ELASI dan Ujian Nasional bahasa Inggris konvensional disajikan dalam tabel berikut.

Tabel 1. Komponen-komponen penilaian pada Ujian Nasional bahasa Inggris versi ELASI dan Ujian Nasional bahasa Inggris konvensional

\begin{tabular}{|c|c|c|}
\hline $\begin{array}{l}\text { Jenis Ujian } \\
\text { Nasional } \\
\begin{array}{l}\text { Komponen } \\
\text { Penilaian }\end{array}\end{array}$ & $\begin{array}{l}\text { Ujian Nasional Bahasa Inggris } \\
\text { Versi ELASI }\end{array}$ & $\begin{array}{l}\text { Ujian Nasional Bahasa Inggris } \\
\text { Konvensional }\end{array}$ \\
\hline \multirow{4}{*}{$\begin{array}{l}\text { Keterampilan } \\
\text { mendengarkan }\end{array}$} & Bentuk tes & \\
\hline & $\begin{array}{l}\text { - PG } \\
\text { - Isian singkat } \\
\text { - Menjodohkan }\end{array}$ & $\mathrm{PG}$ \\
\hline & Jumlah soal dan durasi & \\
\hline & 40 butir; $50-60$ menit & $\begin{array}{l}15 \text { butir; } 15-20 \text { menit (terintegerasi } \\
\text { dengan uji keterampilan membaca } \\
\text { total durasi } 120 \text { menit) }\end{array}$ \\
\hline \multirow{4}{*}{$\begin{array}{l}\text { Keterampilan } \\
\text { berbicara }\end{array}$} & Bentuk tes & \\
\hline & $\begin{array}{l}\text { Penilaian kinerja berbentuk } \\
\text { presentasi }\end{array}$ & Nihil \\
\hline & Jumlah soal dan durasi & \\
\hline & 1 kali penampilan; 5-7 menit & Nihil \\
\hline \multirow{4}{*}{$\begin{array}{l}\text { Keterampilan } \\
\text { membaca }\end{array}$} & Bentuk tes & \\
\hline & $\begin{array}{l}\text { - PG } \\
\text { - Isian singkat } \\
\text { - Menjodohkan }\end{array}$ & $\mathrm{PG}$ \\
\hline & Jumlah soal dan durasi & \\
\hline & 40 butir; 60 menit & $\begin{array}{l}35 \text { butir; } 100-105 \text { menit } \\
\text { (terintegerasi dengan uji } \\
\text { keterampilan mendengarkan total } \\
\text { durasi } 120 \text { menit) }\end{array}$ \\
\hline \multirow{4}{*}{$\begin{array}{l}\text { Keterampilan } \\
\text { menulis }\end{array}$} & Bentuk tes & \\
\hline & $\begin{array}{l}\text { Penilaian kinerja: } \\
\text { - Esai opini/argumentasi }\end{array}$ & Nihil \\
\hline & Jumlah soal dan durasi & \\
\hline & $\begin{array}{l}1 \text { karangan esai yang terdiri atas } \\
150-200 \text { kata; } 30 \text { menit }\end{array}$ & Nihil \\
\hline
\end{tabular}


Keterangan:

Ujian Nasional bahasa Inggris yang diterapkan sesuai gagasan penulis, yakni English Language Assessment System in Indonesia (ELASI) memerhatikan isu autentisitas penilaian dengan menguji empat keterampilan. Akan tetapi, Ujian Nasional Bahasa Inggris konvensional hanya menguji dua keterampilan.

\section{Rancangan Operasional Pelaksanaan}

Operasional pelaksanaan sistem penilaian ELASI untuk mendongkrak autentisitas dilakukan melalui tahapan $6 \mathrm{P}$, yakni persiapan, pelaksanaan, pengolahan hasil, pelaporan hasil, pengevaluasian, dan perbaikan mutu.

\section{Persiapan}

Tahapan persiapan pelaksanaan Ujian Nasional bahasa Inggris versi ELASI mencakup kegiatan-kegiatan berikut ini.

- Penyusunan prosedur operasional standar (POS) penyelenggaraan Ujian Nasional versi ELASI, yakni kegiatan yang meliputi penyusunan dan penyebarluasan informasi mengenai tata cara pelaksanaan Ujian Nasional bahasa Inggris versi ELASI kepada seluruh satuan pendidikan jenjang SMA di Indonesia.

- Penyusunan kisi-kisi Ujian Nasional bahasa Inggris versi ELASI, yakni kegiatan yang dilaksanakan sebelum tahapan penyusunan instrumen tes. Tahapan ini merupakan kegiatan penjaminan mutu tes. Anderson dan Morgan (2008) menjelaskan bahwa kisi-kisi tes merupakan panduan dalam pengembangan butir soal yang bertujuan untuk menjamin mutu soal yang dikonstruksi.

- Penyusunan instrumen tes, yakni kegiatan pengembangan butir soal beserta instruksi pengerjaan yang dikonstruksi berdasarkan kisi-kisi yang telah disusun pada tahapan sebelumnya. Dengan kata lain, instrumen tes merupakan produk lanjutan dari kisi-kisi.

\section{Pelaksanaan}

Pada tahapan pelaksanaan Ujian Nasional bahasa Inggris versi ELASI, terdapat dua model ujian, yakni ELASI berbasis kertas atau Paper-Based Test (PBT) dan ELASI berbasis komputer atau Computer-Based Test (CBT). Ujian Nasional bahasa Inggris versi ELASI mengutamakan model Computer-Based Test (CBT). Akan tetapi, ELASI Paper-Based Test (PBT) akan diterapkan bagi satuan pendidikan yang mengalami kendala dalam ketersediaan fasilitas berupa perangkat komputer dan jaringan internet.

Perbandingan antara ELASI Computer-Based Test (CBT) dan ELASI Paper-Based Test (PBT) ditampilkan dalam tabel berikut ini. 
(PBT)

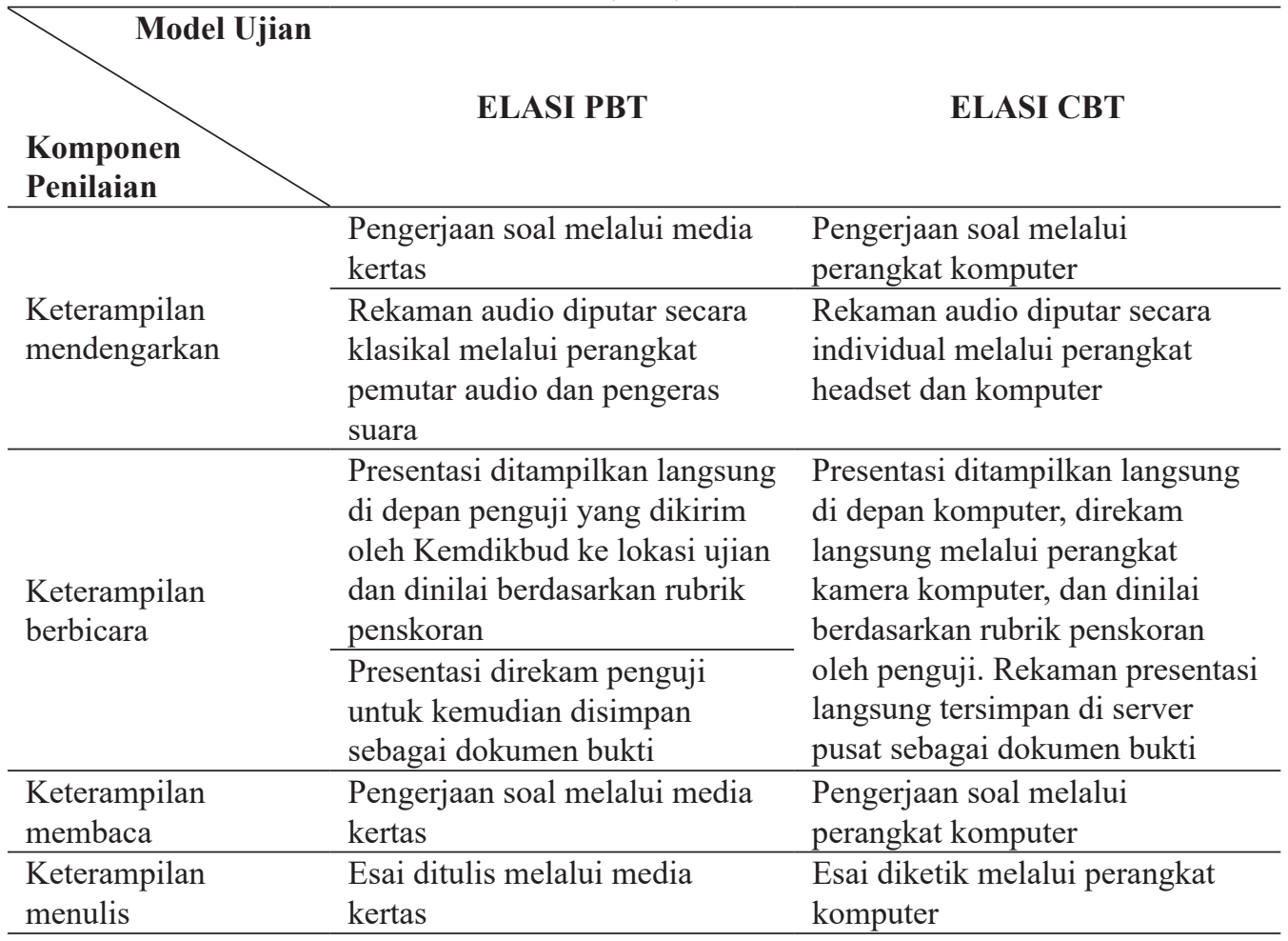

- Pengolahan hasil

Proses pengolahan hasil dilaksanakan untuk masing-masing keterampilan. Hal ini mengisyaratkan bahwa skor perolehan mencerminkan kemampuan peserta didik pada masing-masing keterampilan secara terpisah. Sistem komputerisasi diterapkan pada penskoran jawaban pada butir tes pilihan ganda. Sedangkan untuk penilaian berbasis kinerja pada keterampilan berbicara dan keterampilan menulis, rubrik penskoran dikembangkan untuk meminimalisir aspek subjektivitas dalam penskoran. Pada akhirnya, skor perolehan masing-masing uji keterampilan tersebut dirata-ratakan sebagai nilai akhir. Nilai akhir ini yang memberikan gambaran atas kemampuan bahasa Inggris peserta didik secara umum.

- Pelaporan hasil

Tahapan pelaporan hasil capaian Ujian Nasional bahasa Inggris mencakup tiga sub tahapan, yakni pencetakan dokumen laporan hasil ujian oleh Kemdikbud, pendistribusian dokumen laporan oleh Kemdikbud ke satuan pendidikan, dan pengumuman serta penyerahan dokumen hasil ujian kepada peserta didik. Pada tahap ini, ELASI menampilkan profil capaian kemampuan bahasa Inggris peserta didik. Nilai akhir ujian ELASI dilaporkan dalam bentuk pemenuhan kriteria pencapaian kompetensi lulusan sebagai berikut. 
Tabel 3. Kriteria pencapaian kompetensi lulusan ELASI

\begin{tabular}{ccl}
\hline Nilai & Predikat & \multicolumn{1}{c}{ Deskripsi Kompetensi } \\
\hline $81-100$ & Sangat baik & $\begin{array}{l}\text { Memiliki akurasi dan kefasihan yang SANGAT BAIK dalam } \\
\text { pemahaman dan keterampilan Bahasa Inggris }\end{array}$ \\
\hline $71-80$ & Baik & $\begin{array}{l}\text { Memiliki akurasi dan kefasihan yang BAIK dalam pemahaman } \\
\text { dan keterampilan Bahasa Inggris }\end{array}$ \\
\hline $61-70$ & Cukup & $\begin{array}{l}\text { Memiliki akurasi dan kefasihan yang CUKUP dalam pemahaman } \\
\text { dan keterampilan Bahasa Inggris }\end{array}$ \\
\hline $51-60$ & Kurang & $\begin{array}{l}\text { Memiliki akurasi dan kefasihan yang KURANG dalam } \\
\text { pemahaman dan keterampilan Bahasa Inggris }\end{array}$ \\
\hline $1-50$ & Sangat & $\begin{array}{l}\text { Memiliki akurasi dan kefasihan yang SANGAT KURANG dalam } \\
\text { pemahaman dan keterampilan Bahasa Inggris }\end{array}$ \\
\hline
\end{tabular}

- Evaluasi

Tahapan evaluasi meliputi dua kegiatan, yaitu evaluasi kualitas pelaksanaan ELASI dan evaluasi mutu perangkat tes. Evaluasi kualitas pelaksanaan ELASI mengarah pada kegiatan mengukur kelemahan operasional yang perlu diperbaiki pada pelaksanaan Ujian Nasional versi ELASI selanjutnya. Sedangkan evaluasi mutu perangkat tes merupakan kegiatan validasi yang dilaksanakan secara berkesinambungan untuk memperoleh pembuktian atas refleksi mutu butir soal (Permendikbud No. 23, 2016).

- Perbaikan mutu

Tahapan terakhir dari operasional pelaksanaan sistem penilaian ELASI berujung pada usaha untuk meningkatkan mutu sistem penilaian dan mutu pembelajaran. Tahapan ini dilaksanakan berdasarkan rekomendasi hasil evaluasi guna memastikan keberhasilan sistem penilaian ELASI dan kontribusinya terhadap pembelajaran bahasa Inggris.

\section{Simpulan}

Urgensi peningkatan autentisitas pada sistem pembelajaran dan penilaian semakin mendesak. Gagasan ilmiah ELASI berorientasi pada pemenuhan autentisitas penilaian dari aspek relevansi karakteristik tes dengan kondisi nyata kehidupan sehari-hari dan implementasi kemampuan berpikir aras tinggi. Manfaat dari eksistensi dan implementasi ELASI bukan hanya peningkatan mutu yang bersifat klasikal, namun untuk lingkup yang lebih luas, yakni peningkatan kualitas sistem pembelajaran dan penilaian bahasa Inggris secara nasional.

Penulis memiliki keyakinan tinggi bahwa jika gagasan tersebut diterapkan di dalam Ujian Nasional bahasa Inggris, niscaya isu autentisitas penilaian maupun pembelajaran bahasa Inggris tidak akan lagi memantik perdebatan. Pada akhirnya, pemerintah dalam hal ini Kementerian Pendidikan dan Kebudayaan dapat mengambil keputusan yang lebih tepat sasaran berdasarkan hasil ujian tersebut dalam rangka peningkatan mutu pembelajaran dan penilaian bahasa Inggris yang autentik bagi peserta didik di seluruh satuan pendidikan dalam Negara Kesatuan Republik Indonesia.

\section{DAFTAR RUJUKAN}

Abedi, J. (2010). Performance Assessments for English Language Learners. Stanford, CA: Stanford University, Stanford Center for Opportunity Policy in Education.

Anderson, P. \& Morgan, G. (2008). Developing Tests and Questionnaires for a National Assessment of Educational Achievement (Vol. 1). Washington, DC: The World Bank.

Badan Standar Nasional Pendidikan. (2017). Surat Keputusan BSNP Nomor: 0282/SKEP/ BSNPVIII/2017 tanggal 1 Agustus 2017 tentang Kisi-kisi UN untuk Satuan Pendidikan 
Dasar dan Menengah Tahun Pelajaran 2017/2018, beserta Lampiran Kisi-kisi. Jakarta: Badan Standar Nasional Pendidikan.

Chandio, M. T. \& Jafferi, S. (2015). "Teaching English as A Language Not Subject by Employing Formative Assessment”. Journal of Education and Educational Development, 2(2): hlm.151-171.

Giraldo, F. (2018). "Language Assessfment Literacy: Implications for Language Teachers". Profile: Issues in Teachers' Professional Development, 20(1): hlm.179-195.

Halili, S. H. (2015). "Effective Teaching of Higher-Order Thinking (Hot) In Education". The Online Journal of Distance Education and e-Learning, 3(2): hlm.41-47.

Hughes, J. (2014). Critical Thinking in the Language Classroom. Oxford: ELI.

Karakoc, M. (2016). "The Significance of Critical Thinking Ability in terms of Education". International Journal of Humanities and Social Science, 6(7): hlm. 81-84.

Menteri Pendidikan dan Kebudayaan Republik Indonesia. (2016). Peraturan Menteri Pendidikan dan Kebudayaan Republik Indonesia Nomor 23 Tahun 2016 tentang Standar Penilaian Pendidikan. Jakarta: Kementerian Pendidikan dan Kebudayaan Republik Indonesia.

Palm, T. (2008). "Performance Assessment and Authentic Assessment: A Conceptual Analysis of the Literature". Practical Assessment Research \& Evaluation, 13(4): hlm.1-11.

Undang-Undang Republik Indonesia Nomor 20 Tahun 2003 tentang Sistem Pendidikan Nasional. Jakarta: Presiden Republik Indonesia.

Valencia, S.W dkk. (2014). Authentic Reading Assessment: Practices and Possibilities. California: TextProject, Inc. 